\title{
Isolated Breast Relapse Mimicking Breast Cancer in Elderly Patient with Acute Lymphoblastic Leukemia
}

\section{Akut Lenfoblastik Lösemi Tanısı Olan İleri Yaş Hastada Meme Kanserini Taklit Eden İzole Meme Nüksü}

\author{
Ajay Gogial, Prashant Mehtal, Raja Pramanik1, Rajive Kumar² \\ ${ }^{1}$ Dr. B.R.A. Institute Rotary Cancer Hospital All India Institute of Medical Sciences, Department of Medical Oncology, New Delhi, India \\ ${ }^{2}$ Dr. B.R.A. Institute Rotary Cancer Hospital All India Institute of Medical Sciences, Lab of Oncology, New Delhi, India
}

To the Editor,

Acute lymphoblastic leukemia (ALL) in adults is associated with high relapse rates. Isolated extramedullary relapse other than in the central nervous system is rare in adult females with ALL. We present a case of isolated breast relapse in a 65-year-old female with ALL, mimicking breast cancer.

A 65-year old female presented with a 2-month history of fever and generalized lymphadenopathy in December 2006. Physical examination revealed generalized lymphadenopathy and hepatosplenomegaly. Her hemoglobin was $11.9 \mathrm{~g} / \mathrm{dL}$, total leukocyte count $9.2 \times 109 / \mathrm{L}$, and platelet count 106x109/L. Peripheral blood smear showed 5\% myeloperoxidase-negative blast cells and the bone marrow revealed near total replacement with lymphoblasts (Figures $1 \mathrm{~A}$ and $1 \mathrm{~B}$ ), which on flow cytometry were positive for CD19 and CD22 and negative for CD10, CD5, and CD7. The cerebrospinal fluid was uninvolved. She was diagnosed with pre-B ALL and received induction as per the MCP-841 protocol [1]. Remission was achieved at the end of induction chemotherapy. Thereafter, she completed intensification, followed by oral maintenance for 1.5 years. Twenty-four months later, she presented with a lump in the left breast. On clinical examination, she had a large, non-tender mass in her left breast with a 1-cm mobile axillary lymph node on the same side. Systemic examination was normal. We considered a diagnosis of breast cancer in view of the classical presentation, supported by a mammogram finding suggestive of Breast Imaging Reporting and Data System Score V (Figures $1 \mathrm{C}$ and $1 \mathrm{D})$. Blood counts, peripheral blood smear, and bone

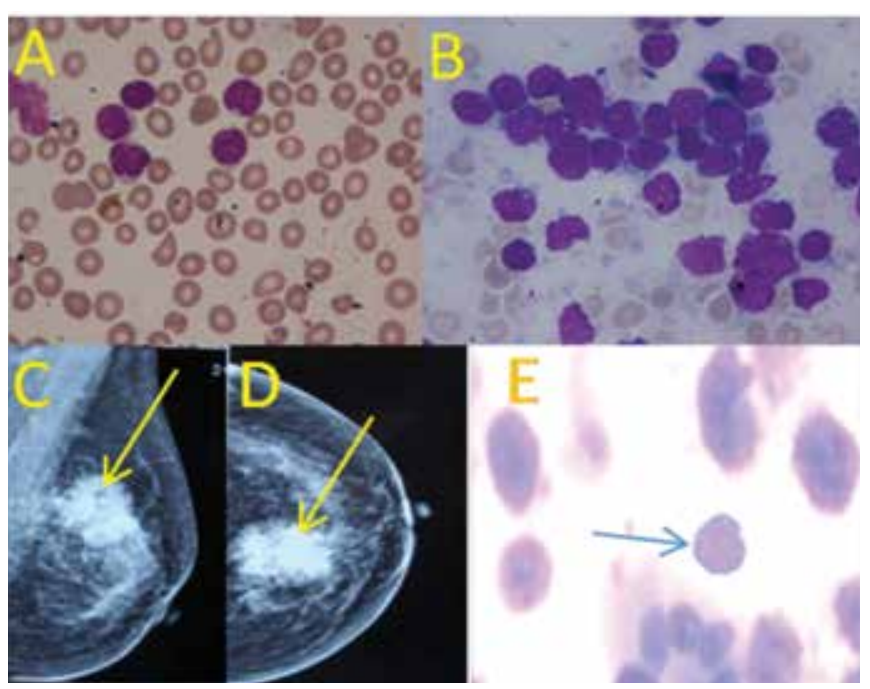

Figure 1. Peripheral blood smear and bone marrow aspirate (A\&B) show lymphoblasts with coarse chromatin and high nuclear cytoplasmic ratio (Jenner-Giemsa stain, 1000x). Mediolateral oblique and cranio-caudal views of the mammogram show homogeneous mass with architectural distortion and microcalcification (C\&D). Fine-needle aspiration shows immature lymphoid cell with duct (400X) (E).

Address for Correspondence: Ajay GOGİA, M.D.,

Dr. B.R.A. Institute Rotary Cancer Hospital All India Institute of Medical Sciences, Department of Medical Oncology, New Delhi, India 
Table 1. Cases of isolated breast relapse in adult ALL.

\begin{tabular}{|c|c|c|c|c|c|c|}
\hline Reference & $\begin{array}{l}\text { Age } \\
\text { (years) at } \\
\text { presentation }\end{array}$ & Sex & $\begin{array}{l}\text { Treatment-free } \\
\text { interval }\end{array}$ & $\begin{array}{l}\text { Total } \\
\text { leukocyte } \\
\text { count }\end{array}$ & $\begin{array}{l}\text { Type of } \\
\text { ALL }\end{array}$ & Outcome \\
\hline Sagar et al. [4] & 35 & Female & 2.5 years & $100 \times 10^{9} / \mathrm{L}$ & $\begin{array}{l}\text { Not } \\
\text { available }\end{array}$ & Not available \\
\hline Chim et al. [5] & 23 & Male & 1.5 years & $260 \times 10^{9} / \mathrm{L}$ & T-cell & $\begin{array}{l}\text { Died } 7 \\
\text { months after } \\
\text { diagnosis }\end{array}$ \\
\hline Basara et al. [6] & 32 & Female & 4 years & Not available & Pre-B & $\begin{array}{l}\text { Died during } \\
\text { induction }\end{array}$ \\
\hline $\begin{array}{l}\text { Karbasian- } \\
\text { Esfahani et al. [7] }\end{array}$ & 30 & Female & 1 year & $400 \times 10^{9} / \mathrm{L}$ & $\begin{array}{l}\text { Not } \\
\text { available }\end{array}$ & $\begin{array}{l}\text { Alive and } \\
\text { disease-free }\end{array}$ \\
\hline Present case & 65 & Female & 2 years & $9.2 \times 10^{9} / \mathrm{L}$ & Pre-B & $\begin{array}{l}\text { Alive and } \\
\text { disease-free }\end{array}$ \\
\hline
\end{tabular}

marrow were unremarkable. Fine-needle aspiration of the breast lump and axillary lymph node showed a monomorphic population of immature cells with a high nuclear/cytoplasmic ratio and prominent nucleoli, suggestive of leukemic blasts (Figure 1E). The blasts were positive for CD45, CD19, and $\mathrm{CD} 22$ and negative for CD3, CD5, CD7, CD10, and MPO on flow cytometry. A diagnosis of ALL relapse was made. Further investigations failed to reveal any other extramedullary site of involvement. She was given reinduction using the same treatment protocol. Response assessment done at the end of induction therapy showed complete resolution of the breast lump. The patient has been asymptomatic and disease-free for the last 2 years. Informed consent was obtained.

The most common sites of relapse in ALL are the marrow, the central nervous system, and occasionally the ovaries. Breast involvement is not so rare in ALL but is usually seen in teenagers and is generally associated with the disease at other extramedullary sites as well as the bone marrow [2]. The published literature revealed a total of 14 cases of isolated breast relapse in ALL. The median age in those patients was 16 years [3]. Four cases with similar presentation of adult ALL have been published (Table 1) [4,5,6,7]. Sagar et al. reported a similar occurrence in a 35-year-old female, but details on immunophenotyping, response, remission status, and outcome were not available [4]. Chim et al. reported a similar case in a 23-year-old male with previous diagnosis of T-cell ALL who died of progressive disease after 7 months of relapse [5]. Two other cases with similar presentation have been reported [6,7]. All patients reported with adult ALL were between the ages of 23 and 35 years. Our patient was 69 years old at the time of relapse, and her clinical findings closely resembled breast cancer, a malignancy more common for her age. It is important that clinicians be aware that the breast may be a site of relapse in adult females with ALL and hence include breast examination during follow-up.

\section{Conflict of Interest Statement}

The authors of this paper have no conflicts of interest, including specific financial interests, relationships, and/ or affiliations relevant to the subject matter or materials included.

Key Words: Acute lymphoblastic leukemia, Isolated breast relapse

Anahtar Sözcükler: Akut lenfoblastik lösemi, İzole meme nüksü

\section{References}

1. Vaidya SJ, Advani SH, Pai SK, Nair CN, Kurkure PA, Saikia TK, Gopal R, Pai VR, Nadkarni KS, Parikh PM. Survival of childhood acute lymphoblastic leukemia: results of therapy at Tata Memorial Hospital, Bombay, India. Leuk Lymphoma 1996;20:311-315.

2. Todo K, Morimoto A, Osone S, Nukina S, Ohtsuka T, Ishida $\mathrm{H}$, Yoshihara $\mathrm{T}$, Todo $\mathrm{S}$. Isolated relapse of acute lymphoblastic leukemia in the breast of a young female. Pediatr Hematol Oncol 2008;25:607-613.

3. Farah RA, Timmons CF, Aquino VM. Relapsed childhood acute lymphoblastic leukemia presenting as an isolated breast mass. Clin Pediatr (Phila) 1999;38:545-546.

4. Sagar TG, Maitreyan V, Majhi U, Shanta V. Breast involvement in acute lymphoblastic leukaemia. J Assoc Physicians India 1989;37:718-719.

5. Chim CS, Shek TW, Liang R. Isolated relapse of acute lymphoblastic leukemia in the breast masquerading as gynecomastia. Am J Med 2000;108:677-679.

6. Basara I, Orguc SJ. Giant breast involvement in acute lymphoblastic leukemia: MRI findings. J Breast Cancer 2012;15:258-260.

7. Karbasian-Esfahani M, Wiernik PH, Yeddu M, Abebe L. Leukemic infiltration of the breast in acute lymphocytic leukemia (ALL). Hematology 2008;13:101-106. 